\title{
Development of mammary luminal progenitor cells is controlled by the transcription factor STAT5A
}

\section{Daisuke Yamaji, ${ }^{1}$ Risu Na, ${ }^{1}$ Yonatan Feuermann, ${ }^{1}$ Susanne Pechhold, ${ }^{2}$ Weiping Chen, ${ }^{3}$ Gertraud W. Robinson, ${ }^{1,5}$ and Lothar Hennighausen ${ }^{1,4}$}

\begin{abstract}
${ }^{1}$ Laboratory of Genetics and Physiology, National Institute of Diabetes and Digestive and Kidney Diseases, National Institutes of Health, Bethesda, Maryland 20892, USA; ${ }^{2}$ Diabetes Branch, National Institute of Diabetes and Digestive and Kidney Diseases, National Institutes of Health, Bethesda, Maryland 20892, USA; ${ }^{3}$ Genomics Core Laboratory, National Institute of Diabetes and Digestive and Kidney Diseases, National Institutes of Health, Bethesda, Maryland 20892, USA
\end{abstract}

\begin{abstract}
Mammary alveologenesis is abrogated in the absence of the transcription factors STAT5A/5B, which mediate cytokine signaling. To reveal the underlying causes for this developmental block, we studied mammary stem and progenitor cells. While loss of STAT5A/5B did not affect the stem cell population and its ability to form mammary ducts, luminal progenitors were greatly reduced and unable to form alveoli during pregnancy. Temporally controlled expression of transgenic STAT5A in mammary epithelium lacking STAT5A/5B restored the luminal progenitor population and rescued alveologenesis in a reversible fashion in vivo. Thus, STAT5A is necessary and sufficient for the establishment of luminal progenitor cells.
\end{abstract}

Supplemental material is available at http://www.genesdev.org.

Received July 6, 2009; revised version accepted September 1, 2009.

STAT5A and STAT5B, collectively referred to as STAT5A/5B, are two highly conserved transcription factors activated by various cytokines-including prolactin, growth hormone, and EGF-that play important roles in the development and function of mammary glands, hematopoietic cells, liver, and muscle (Hennighausen and Robinson 2008). Deletion of the Stat5a gene in the germline results in impaired mammary alveologenesis during pregnancy (Liu et al. 1997). However, in the absence of Stat5a, increased expression of STAT5B after several pregnancies partially rescued the lactation defect (Liu et al. 1998). Deletion of Stat $5 b$ had no effect on mammary epithelial cells (Udy et al. 1997; Teglund et al. 1998). In subsequent studies using germline deletion, as well as

[Keywords: STAT5; alveologenesis; mammary gland; progenitor; CD61; tetracycline]

Corresponding authors.

${ }^{4}$ E-MAIL lotharh@mail.nih.gov; FAX (301) 480-7312

${ }^{5}$ E-MAIL traudl@nih.gov; FAX (301) 480-7312.

Article is online at http://www.genesdev.org/cgi/doi/10.1101/gad.1840109. mammary epithelial-specific ablation, of both Stat5a and Stat $5 b$ genes, the role of STAT5A/5B during mammary gland development was investigated (Miyoshi et al. 2001; Cui et al. 2004). We discovered that the deletion of both Stat $5 a / 5 b$ genes in mammary epithelium resulted in a severe defect of alveologenesis, and that the presence of STAT5A/5B was essential for the proliferation, differentiation, and survival of mammary epithelial cells.

Mammary epithelium consists of two types of cells: basal myoepithelial cells and luminal cells, which form a ductal tree in virgins and alveoli during pregnancy. These events are coordinated by systemic hormones and cytokines (Hennighausen and Robinson 2005). Elaboration of mature epithelium from stem cells is thought to proceed in a hierarchical progression. Stem cells give rise to transient amplified progenitor cells capable of generating ductal and alveolar structures that become restricted to only ductal or alveolar fates and eventually give rise to differentiated lineages (Stingl 2009). In recent years, a combination of enzyme digestion and fluorescence-activated cell sorting (FACS) techniques have been developed to allow the isolation of these different cell populations from single-cell suspensions derived from mammary tissue of virgin female mice (Shackleton et al. 2006; Stingl et al. 2006). This knowledge enabled us to study the role of STAT5A/5B in a defined cell population of mammary epithelium.

STAT5A/5B control stem and progenitor cell fate in the hematopoietic system (Wang et al. 2009). In the absence of STAT5A/B, mice fail to develop T, B, and natural killer cells (Hoelbl et al. 2006; Yao et al. 2006). STAT5A/5B are also required for the maintenance and expansion of primitive stem and progenitor cells, both in normal and leukemic hematopoiesis (Li et al. 2007; Liu et al. 2008). These studies support our proposal that STAT5A/5B are critical for mammary cell lineage development from primitive stem/progenitor cells.

Several mechanisms might account for the lack of alveolar development in the absence of STAT5A/5B: (1) Stem cells are defective and fail to generate alveolar progenitor cells. (2) Although stem cells generate alveolar progenitor cells, progenitors cannot proliferate or survive. (3) Although stem cells give rise to alveolar progenitor cells that can proliferate and survive, progenitors do not generate daughter alveolar cells. (4) STAT5A/B play a role only in differentiated alveolar cells. To test these hypotheses, we isolated and analyzed epithelial stem and progenitor cell populations from mammary epithelium containing or lacking STAT5A/5B.

\section{Results and Discussion}

The mammary luminal progenitor cell population is reduced in the absence of STAT5A/5B

To ask which of the steps in the lineage progression of mammary stem cells to functional secretory epithelium is dependent on the presence of STAT5A/5B, we used conditional gene deletion with a MMTV-Cre transgenic mouse line that affects all epithelial cells of the newborn as determined with a lacZ reporter construct. Therefore, we consider the entire epithelium null for Stat $5 a / 5 b$ (Wagner et al. 1997, 2001; Buono et al. 2006). Our observation that Stat $5 a / 5 b^{\text {flifl; Cre }}$ mice could not lactate 
even after five to six pregnancies further supports this. We prepared single-cell suspensions from mammary tissue of nulliparous mature female Stat $5 a / 5 b^{f l / f 1}$ and Stat $5 a / 5 b^{f l / f l ; C r e}$ mice and performed flow cytometry analysis using antibodies against CD24, CD49f, and CD61 (Stingl et al. 2006; Asselin-Labat et al. 2007). Both Stat5a/5b fl/f1 and Stat $5 a / 5 b^{\text {fl/ff;Cre }}$ virgin mice showed similar dot plot patterns that defined four cell populations: negative $\left(\mathrm{CD} 24^{-} \mathrm{CD}^{2} 9 \mathrm{f}^{-}\right)$, luminal (CD24 ${ }^{\text {hi }} \mathrm{CD} 49 \mathrm{f}^{\mathrm{lo}}$ ), myoepithelial $\left(\mathrm{CD} 24^{\mathrm{lo}} \mathrm{CD} 49 \mathrm{f}^{\mathrm{hi}}\right)^{\prime}$, and the stem cell-enriched upper portion of myoepithelial cells (CD24 ${ }^{\text {mid }}$ CD $49 f^{\text {hi }}$ ) (Fig. 1A). Percentages of each population in Stat $5 a / 5 b^{f l / f l}$ mice versus Stat $5 a /$ $5 b^{f l f f l ; C r e}$ mice were $11.1 \% \pm 0.97 \%$ versus $11.5 \% \pm 1.33 \%$ in luminal, $19.0 \% \pm 3.06 \%$ versus $11.3 \% \pm 1.82 \%$ in myoepithelial, and $3.38 \% \pm 0.33 \%$ versus $2.00 \% \pm 0.40 \%$ in stem cell-enriched populations, respectively. Quantita-
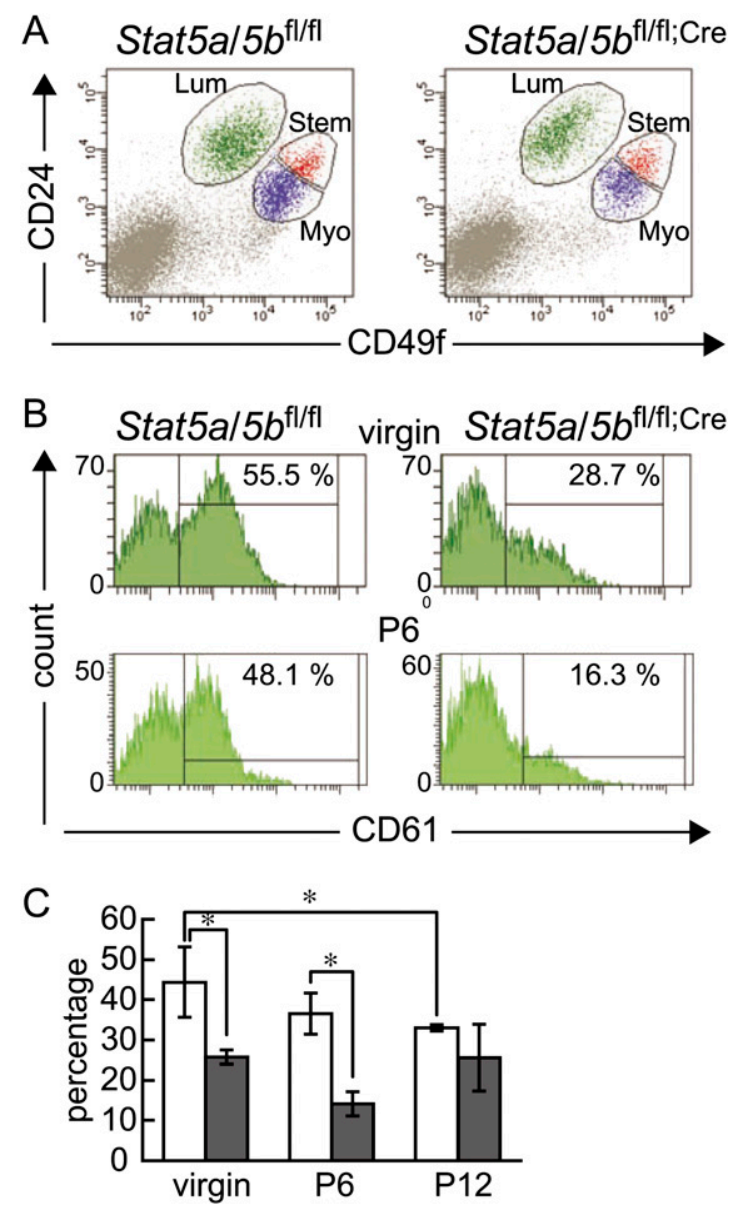

Figure 1. Flow cytometry analyses of mammary cells from Stat5a/ $5 b^{f 1 / f 1}$ mice (left panels) and Stat $5 a / 5 b^{f 1 / f l ; C r e}$ mice (right panels). (A) Dot plot pattern of luminal (Lum; CD24 ${ }^{\text {hi }}$ CD $49 f^{l o}$ ), myoepithelial (Myo; CD24 ${ }^{\text {lo }} \mathrm{CD} 49 \mathrm{f}^{\text {hi }}$ ) and stem cell-enriched (Stem; CD24 ${ }^{\text {mid }} \mathrm{CD} 49 \mathrm{f}^{\text {hi }}$ ) populations in 12-wk-old virgin mice. $(B)$ CD61 staining histograms of luminal cell population (CD2 $4{ }^{\text {hi }} \mathrm{CD} 49 \mathrm{f}^{\mathrm{lo}}$ ) in the mammary gland of 12 -wk-old virgin mice (top panels) and $6 \mathrm{~d}$ pregnant mice (P6, bottom panels). The $\mathrm{CD}^{+} 1^{+}$population was determined according to fluorescence minus one (FMO) control of the same mouse. (C) Bar graph depicting the percentage of $\mathrm{CD} 1^{+}$cells in luminal cell populations of Stat $5 a / 5 b^{f 1 / f 1}$ (blank bars) and Stat $5 a / 5 b^{f 1 / f 1 ; C r e}$ (filled bars) mammary glands in virgins, and on day 6 (P6) and day $12(\mathrm{P} 12)$ of pregnancy. Values are means $\pm \mathrm{SD} .\left(^{\star}\right) P<0.05$. tive real-time RT-PCR analysis revealed that Stat5a and Stat $5 b$ mRNAs were not present in the luminal, myoepithelial, and stem cell-enriched fractions in mammary

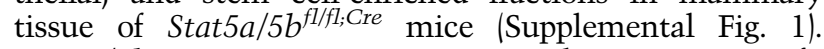
Stat $5 a / 5 b$ mRNAs were present in the CD24-CD $49 \mathrm{f}^{-}$ population in both Stat $5 a / 5 b^{\text {fl/fl }}$ and Stat $5 a / 5 b^{\text {fl/fl;Cre }}$ mice, suggesting that these were of stromal origin. These results corroborate the high deletion efficiency in this MMTV-Cre transgenic line (Wagner et al. 1997, 2001; Buono et al. 2006).

To assess the ability of mammary stem cells to form an entire functional mammary gland in the presence or absence of STAT5A/5B, the FACS-purified stem cellenriched populations were transplanted into cleared fat pads of athymic nude mice. Mammary stem cells from Stat $5 a / 5 b^{f 1 / f 1}$ and Stat $5 a / 5 b^{\text {fl/fl;Cre }}$ mice were able to generate ductal outgrowths with primary and secondary side branches (Supplemental Fig. 2A,B). This is in agreement with the results obtained by transplantation of small pieces of mammary tissue from Stat $5 a / 5 b^{\Delta N / \Delta N}$, another mouse line with a partially disrupted Stat $5 a / 5 b$ locus (Miyoshi et al. 2001). Limiting dilution analyses revealed no difference in the ability of stem cells to generate epithelial outgrowths in the presence or absence of STAT5A/5B (Supplemental Table 1). These results demonstrate that STAT5A/5B are not important for the ability of mammary stem cells to reconstitute both luminal and myoepithelial cell lineages in ducts of virgin mice. To assess alveolar development and differentiation, stem cell-transplanted hosts were mated to induce pregnancy. While Stat $5 a / 5 b^{f l / f 1}$ stem cells were able to develop a full alveolar compartment at term (Supplemental Fig. 2C,E), the epithelial compartment in Stat $5 a / 5 b^{f l / f l ; C r e}$ stem cell transplants remained sparse (Supplemental Fig. 2D,F). Histological analyses demonstrated that outgrow ths from Stat $5 a / 5 b^{f 1 / f 1}$ stem cells had alveoli that consisted of cells secreting milk (Supplemental Fig. 2G,I), while the Stat $5 a / 5 b^{f l / f l ; C r e}$ stem cells produced only a ductal tree with virgin-like characteristics (Supplemental Fig. 2H,J). These results validate earlier studies that alveolar development is inhibited in the absence of STAT5A/5B.

To determine potential causes for the absence of alveolar development, we analyzed luminal progenitor cells. The amount of $\mathrm{CD}^{+} 1^{+}$cells in the luminal cell population was profoundly reduced in Stat $5 a / 5 b^{f 1 / f 1 ; C r e}$ mice $\left(44.4 \%+3.93 \%\right.$ in Stat $5 a / 5 b^{f l / f 1}$ vs. $25.8 \% \pm 0.81 \%$ in Stat $\left.5 a / 5 b^{\overline{f l} / f l \text { Cre }}\right)$ in virgins (Fig. 1B). Furthermore, the $\mathrm{CD} 61^{+}$population was not increased during pregnancy (Fig. 1B,C). This strongly suggests that the CD $61^{+}$luminal progenitor cells present in the Stat $5 a / 5 b^{f l / f l ; C r e}$ mammary gland are ductal luminal progenitor cells, and the reduction in the total number of $\mathrm{CD} 61^{+}$cells reflects an absence of alveolar precursors. Thus, impaired alveologenesis and lactation of Stat $5 a / 5 b$-null mammary epithelium most likely are due to a reduced number of alveolar luminal progenitor cells already in the virgin state.

\section{STAT5A is necessary and sufficient for the generation} of alveolar luminal progenitor cells and mature alveoli

We next asked whether the deficit in $\mathrm{CD} 61^{+}$cells in the ducts of virgin glands and the failure to generate alveoli can be overcome by a temporally defined expression of STAT5A after the ductal system has been established at the end of puberty. Mice were generated that carried a Stat $5 a$ transgene under control of the tetracycline-inducible 
promoter (tet-op-Stat5a), as well as MMTV-rtTA (Gunther et al. 2002) and MMTV-Cre transgenes and two floxed Stat $5 a / 5 b$ alleles $\left(\right.$ Stat $\left.5 a / 5 b^{\text {fl/fl; Cre } ; \text { iStat } 5}\right)$. These experimental mice were fed with doxycyline-containing food to induce transgenic expression of Stat5a and were continuously mated. Mice being exposed to doxycycline during pregnancy developed functional mammary glands during pregnancy and were able to feed their pups. In order to demonstrate the dependence of mammary development and lactation on the expression of transgenic STAT5A induced by doxycycline, successfully nursing dams were switched to regular food after weaning of the second litter. Insufficient amounts of milk were present and pups of the third and fourth litters did not survive. Return to doxycycline food, and therefore expression of transgenic Stat5a, after the death of the fourth litter resulted in the survival of two more litters.

Mammary tissue samples from the Stat $5 a / 5 b^{\text {fl/fl; Cre } ; \text { iStat } 5}$ mice taken by biopsy in the morning after delivering the first, fourth, and sixth litters were analyzed by histology and immunofluorescence staining (Fig. 2A). Expanded alveoli lined with differentiated secretory cells were found after doxycycline treatment (Fig. 2B, panel a). The lumen contained proteinaceous material and lipid droplets. In the absence of doxycycline, the alveoli were small, secretory cells appeared undifferentiated, and the lumina were unexpanded and devoid of lipid droplets (Fig. 2B, panel b). Activated STAT5 was found in the majority of nuclei after doxycycline treatment, but was scarce in the absence of doxycycline (Fig. 2B, panels d,e). Epithelial differentiation was reversed when expression of exogenous STAT5A was abolished and could be induced again upon stimulation of
STAT5A expression (Fig. 2B, panels c,f). Furthermore, staining of the sodium/potassium/cotransporter 1 (NKCC1), a protein expressed in undifferentiated ductal cells of virgin and early pregnancy stages (Shillingford et al. 2002), was seen in few luminal cells in the samples from the first and sixth lactation, but was strongly expressed in the absence of doxycycline after the fourth pregnancy (data not shown). These results show that the presence of only STAT5A during pregnancy leads to the formation of alveolar structures and functional differentiation of luminal cells. It clearly indicates that Stat $5 a / 5 b$-deficient mammary epithelium contains stem cells that are capable of differentiation along the ductal but not alveolar luminal cell lineage, and luminal cell fate depends on STAT5A.

To evaluate the role of STAT5A in the generation of alveolar luminal progenitor cells, flow cytometry analyses were performed with mammary tissues of Stat 5 al $5 b^{f l / f l ; C r e ; \text { iStat } 5}$ mice 4 wk after weaning (Fig. 3). When fed with doxycycline food, the Stat $5 a / 5 b^{\text {fl/fl;Creistat } 5}$ mice were able to generate $\mathrm{CD} 61^{+}$luminal progenitor cells during pregnancy to a similar extent as Stat $5 a / b^{f 1 / f 1}$ mice. In contrast, the number of $\mathrm{CD} 1^{+}$luminal progenitor cells in the mammary glands of Stat $5 a / b^{f l / f l ; C r e ; \text { iStat } 5}$ mice fed with normal diet was comparable with that of Stat $5 a / 5 b^{\text {fl/fl; Cre }}$ mice. These results demonstrate that expression of STAT5A in the Stat $5 a / 5 b$-deficient mammary epithelium was necessary and sufficient for the generation of luminal progenitor cells in the quiescent gland and alveologenesis during pregnancy.

We performed genome-wide microarray analyses to investigate changes in the gene expression profile of Stat $5 a / 5 b^{f l / f l}$ and Stat $5 a / 5 b^{f l / f l ; C r e}$ mammary tissues on day 6 of pregnancy. We considered this a stage that would allow the identification of genes that are involved in the early stages of luminal cell proliferation and differentiation and are induced by STAT5. Besides $\beta$-casein, cyclin D1, and connexin 26 (Hennighausen and Robinson 2005), which are known STAT5 target genes, Gene Ontology analyses showed decreased expression of genes involved in regulation of the cell cycle, DNA metabolic processes, response to DNA damage stimuli, and chromosome organization pathways in Stat $5 a / 5 b$ deleted samples (Supplemental Table 2). These genes may be either directly transcribed by STAT5 or represent targets of genomic regulatory networks activated by STAT5 in the early phase of pregnancy that is characterized by proliferation and rapid expansion of cells.

Impaired mammary development also occurs in Gata3- and Elf5-deficient mammary epithelium (Asselin-Labat et al. 2007; Oakes et al. 2008). To explore a possible link between these transcription factors and STAT5A, we measured the expression of these two genes in the stem and progenitor cell fractions. mRNA levels of Gata3 were similar in both cell populations, irrespective of the genotype (Supplemental Fig. 3). However, expression 


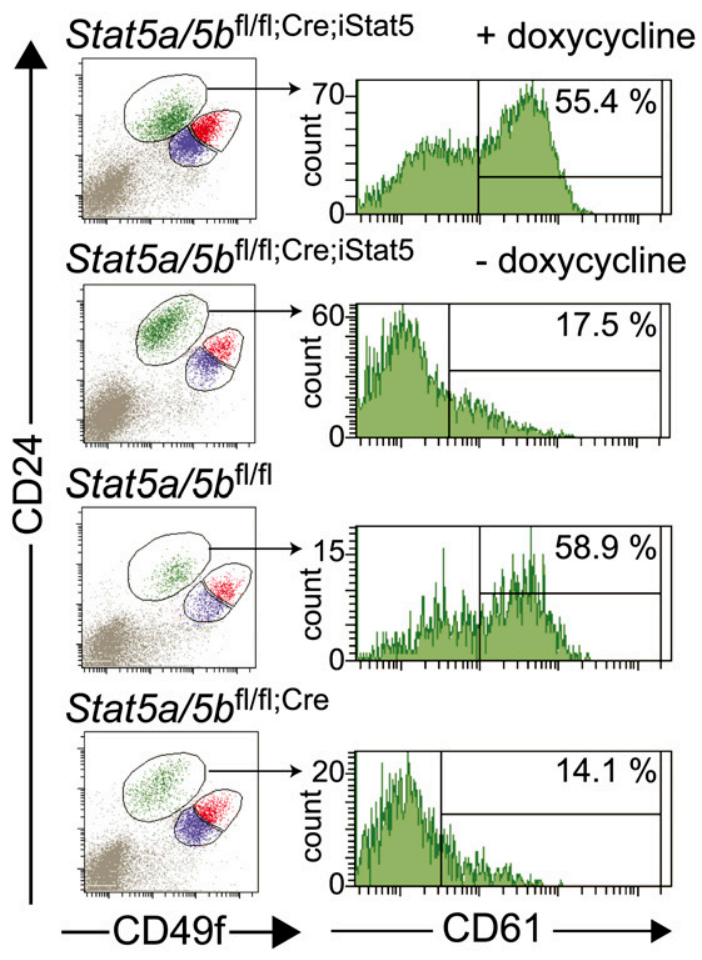

Figure 3. Flow cytometry analyses of mammary luminal progenitor cells in the presence or absence of STAT5A/5B. Dot plot patterns of CD24 and CD49f populations and histograms of CD61 staining of luminal cell population in the mammary tissue of mice with indicated genotype $4 \mathrm{wk}$ after weaning. Mammary tissues of Stat $5 a / 5 b^{f l / f ; C r e ; i S t a t 5}$ mice were analyzed with or without feeding doxycycline.

of Elf5 was barely detectable in the Stat $5 a / 5 b^{f 1 / f 1 ; C r e}$ cells (Supplemental Fig. 3).

This demonstrates a distinct function for these transcription factors in the different cell lineages (Fig. 4). GATA3, which has been shown to control maintenance of luminal cells in ducts as well as alveoli (Kouros-Mehr et al. 2006; Asselin-Labat et al. 2007), is not regulated by STAT5A/5B. A higher proportion of $\mathrm{CD}^{+} 1^{+}$luminal progenitor cells in Gata3-deficient mammary tissues is observed in virgins and sustained through pregnancy, reflecting a block of differentiation to mature ductal and alveolar luminal cells (Asselin-Labat et al. 2007). Elf5-null mammary epithelium also contains a larger fraction of $\mathrm{CD} 1^{+}$luminal progenitor cells during pregnancy but not in virgins, indicating a block of differentiation to secretory alveolar cells (Oakes et al. 2008). We observed a decrease of $\mathrm{CD} 1^{+}$luminal progenitor cells in the Stat5a/ $5 b$-null mammary epithelium already in virgins and no increase of this cell population during pregnancy. Since ductal morphogenesis is not affected, this indicates that STAT5A/5B regulate the production or expansion of alveolar luminal progenitor cells (Fig. 4). The current lack of surface markers to distinguish ductal and luminal progenitor cells makes it impossible to discriminate the two possibilities. Our results indicate a failure of primitive stem/progenitor cells to generate alveolar luminal progenitor cells in the absence of STAT5A/5B.

We previously identified Elf5 as a gene highly upregulated in lactating mammary tissue (Renou et al. 2003). Like STAT5A/5B, ELF5 is a mediator of the prolactin- receptor signaling pathway (Harris et al. 2006). ELF5 binding to the proximal Stat5a gene promoter in late pregnancy has been demonstrated, and loss of ELF5 in primary mammary epithelial cells resulted in a modest decrease in the overall levels of STAT5A (Choi et al. 2009). Real-time RT-PCR analyses demonstrated that the levels of Elf5 mRNA were lower in Stat $5 a / 5 b^{f 1 / f l ; C r e}$ compared with Stat $5 a / 5 b^{f l / f 1}$, and that Elf5 mRNA was induced to a greater extent by prolactin in mammary tissue of Stat $5 a / 5 b^{\text {fl/fl }}$ mice as compared with Stat $5 a / 5 b^{\text {fl/fl; Cre }}$ mice (Supplemental Fig. 4), indicating cell- and stagespecific cross-regulation of their expression in the course of mammary development. In addition, we found 48 sites of TTCNNNGAA, the consensus STAT5-binding sequence, in the distal region of the Elf5 gene promoter. The closest one to the transcription start site is TTCA GTGAA at 3727 base pairs (bp) upstream. Among the 48 sites, three (at $-111,201$ and $-96,996$, at $-65,696$ and $-62,683$, and at $-51,935$ and $-51,189$ in mice and humans, respectively) plus their flanking sequences are well conserved between humans and mice. This indicates that prolactin-induced Elf5 expression is regulated by STAT5A/ 5B-dependent as well as STAT5-independent mechanisms. Together, induction of Elf5 by prolactin is partially regulated by STAT5A/5B for the proliferation and differentiation of mammary alveolar cells during pregnancy. However, these data are obtained from whole mammary tissue samples rather than enriched cell populations. We found that Stat5a/5b-null luminal progenitor cells did not express Elf5 (Supplemental Fig. 3). The presence of alveolar luminal progenitor cells in Elf5-null mammary epithelium in virgins puts STAT5A/5B above ELF5 in the gene hierarchy (Oakes et al. 2008). It further suggests that the absence of Elf5 expression in the Stat5a/5b-null CD61 ${ }^{+}$ progenitor cells reflects the paucity of alveolar progenitor cells in the Stat $5 a / 5 b$-null mammary epithelium.

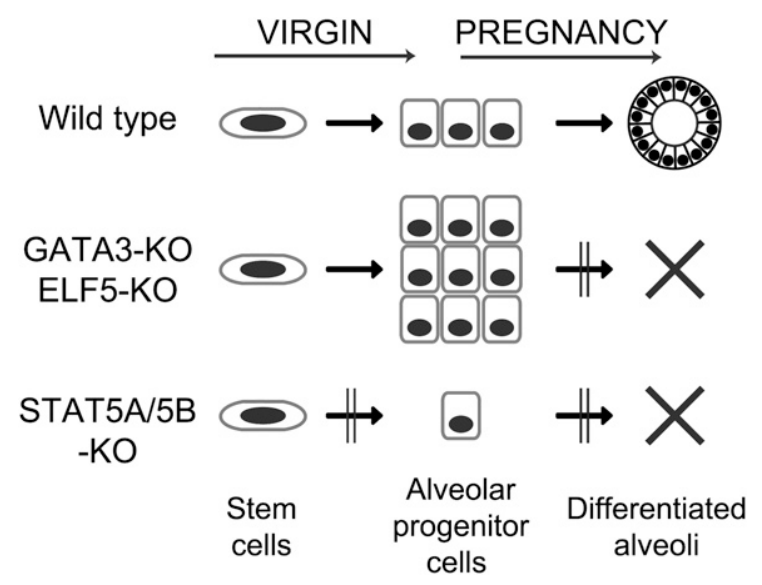

Figure 4. Schematic model depicting the role of STAT5A/5B and other transcription factors in the development of mammary epithelial cell lineages. (Top row) In the wild-type mammary gland, epithelial stem cells generate alveolar luminal progenitor cells that develop mature alveoli during pregnancy. (Middle) Alveolar progenitor cells fail to differentiate into secretory luminal cells in the absence of GATA3 or ELF5, leading to their accumulation in pregnancy and lack of alveolar development. (Bottom row) Loss of STAT5A/5B impairs development of alveolar precursor cells (this study) as well as maintenance of mature alveolar cells as shown previously. 
The reversible generation of luminal progenitor cells and the rescue of alveologenesis by the transgenic expression of STAT5A prove that STAT5A is able to induce the development of the alveolar progenitor lineage in Stat $5 a / 5 b$-null mammary stem cells during pregnancy, even if STAT5A/5B were not present during the ductal development period during puberty. Indeed, mammary alveologenesis was impaired by the germline deletion of Stat5a gene but not Stat5b (Liu et al. 1997; Udy et al. 1997; Teglund et al. 1998). Taken together with our previous findings that STAT5A/5B are critical for the survival and function of alveolar cells during pregnancy (Cui et al. 2004), this supports the notion that STAT5A is required not only for the proliferation or survival of alveolar cells, but also the generation of alveolar progenitors from stem cells. This study provides evidence for a mechanism by which the normal mammary epithelial cell hierarchy is established and maintained through the transcription factor STAT5A.

\section{Materials and methods}

\section{Mouse and genotype analysis}

All animals were handled and housed in accordance with the guidelines of the National Institutes of Health Animal Care and Use Committee. Generation of MMTV-Cre and MMTV-rtTA transgenic mice (kind gift from Dr. L. Chodosh) and Stat $5 a / b^{f l / f 1}$ mice was described previously (Wagner et al. 1997; Gunther et al. 2002; Cui et al. 2004). We mated Stat $5 a / b^{f l / f l}$ mice with the MMTV-Cre transgenic mouse line A in order to generate Stat $5 a / b^{f l / f ; \text { Cre }}$ mice. The presence of Cre recombinase itself did not affect the number of luminal progenitor cells (Supplemental Fig. 5).

\section{Generation of iStat5 (MMTV-rtTA;tet-op-Stat5a) transgenic mice}

Tetracycline-inducible STAT5A transgenic mice were generated by introducing a SacII site into Stat5a cDNA at the 5' ATG start codon and a XbaI site at the 3' TGA stop codon by PCR, using MSCV-IRES-Stat5a as a template and primer set 5'-ATACCGCGGATGGCGGGCTGGATTCA-3' (forward) and 5'-ATATCTAGATCAGGACAGGGAGCTT-3' (reverse). The purified SacII and XbaI fragment was subcloned into plasmid p43 (kindly provided by Dr. Priscilla A Furth), which is composed of the tet operator sequences followed by a CMV minimal promoter and the rabbit $\beta$-globin intron and poly(A) signal at the 3 ' end. The NotI-released DNA fragments were injected into fertilized C57BL/6 eggs (The Jackson Laboratory) to generate transgenic mice according to standard procedures. For PCR analysis of the founders, a primer set 5'-CTGAGTTCGTCAATGCATC CA-3' (forward) and 5'-GGTGATACAAGGGACATCTT-3' (reverse) was designed to detect the unique area of the tet-op-Stat5a. The PCR protocol was 35 cycles of $30 \mathrm{sec}$ at $94^{\circ} \mathrm{C}, 45 \mathrm{sec}$ at $57^{\circ} \mathrm{C}$, and $1 \mathrm{~min}$ at $72^{\circ} \mathrm{C}$. An amplified product of $411 \mathrm{bp}$ from tet-op-Stat $5 a$ was detected.

\section{Preparation of single cells from mammary gland}

Single cells from mammary tissue were prepared as described previously (Stingl et al. 2006) with minor modifications. Briefly, mammary tissue from virgin female $S t a t 5 a / b^{f l / f 1}$ mice and Stat $5 a / b^{f l / f f_{i} \text { Cre }}$ mice at $12-16 \mathrm{wk}$ of age were digested for $8 \mathrm{~h}$ at $37^{\circ} \mathrm{C}$ in complete EpiCult-B medium (EpiCult-B medium with $5 \%$ fetal bovine serum, $10 \mathrm{ng} / \mathrm{mL}$ recombinant human epidermal growth factor, $10 \mathrm{ng} / \mathrm{mL}$ recombinant human basic fibroblast growth factor, $0.0004 \%$ Heparin) supplemented with $300 \mathrm{U} / \mathrm{mL}$ collagenase and $100 \mathrm{U} / \mathrm{mL}$ hyaluronidase. After lysis of red blood cells in $\mathrm{NH}_{4} \mathrm{Cl}$, a single-cell suspension was obtained by sequential dissociation of the fragments with prewarmed $0.25 \%$ trypsin-EDTA for 1-2 min, followed by prewarmed $5 \mathrm{mg} / \mathrm{mL}$ dispase II plus $0.1 \mathrm{mg} / \mathrm{mL}$ DNase I (DNase; Sigma) for $2 \mathrm{~min}$, and filtration through a $70-\mu \mathrm{m}$ mesh. All reagents were from StemCell Technologies, Inc. unless otherwise specified.

\section{FACS analysis and cell sorting}

Prepared single cells were stained with biotinylated anti-CD45, antiTer119, and anti-CD31 antibody (StemCell Technologies); anti-CD24fluorescein isothiocyanate (FITC, clone M1/69, BD Biosciences); antiCD49f-R-phycoerythrin (R-PE, clone GoH3, BD Biosciences); anti-CD61Alexafluor647 (clone 2C9.G2, BioLegend); and 7-amino-actinomycin D (7AAD, BD Biosciences), followed by pacific blue-conjugated streptavidin (Invitrogen). FACS analysis and cell sorting were performed using Diva version 6.1.1 software and FACSAria (BD Biosciences).

\section{Histological analysis}

Harvested mammary tissues were fixed in $10 \%$ formalin, dehydrated through ethanol and xylene, embedded in paraffin, and sectioned. For immunostaining, antigen unmasking was performed in a Decloaking chamber (Biocare Medical) using BORG Decloaker Solution (pH 9.5) (Biocare Medical) for $5 \mathrm{~min}$ at $125^{\circ} \mathrm{C}, 18-24$ PSI. The sections were blocked for $30 \mathrm{~min}$ in TBS-T containing $3 \%$ goat serum. Primary antibodies were incubated overnight at $4^{\circ} \mathrm{C}$ (phosphorylated Stat5, Cell Signaling Technologies, \#9314, 1:200; E-cadherin, BD Biosciences \#610182, 1:200). AlexaFluor488- or AlexaFluor594-conjugated secondary antibodies (Invitrogen) were used at a dilution of 1:400 for $30 \mathrm{~min}$ at room temperature.

\section{Acknowledgments}

We are grateful to Dr. Lewis Chodosh for MMTV-rtTA transgenic mice, Dr. Priscilla Furth for plasmid p43, and all the members of the Laboratory of Genetics and Physiology for helpful discussions. This research was supported by the Intramural Research Program of the National Institute of Diabetes and Digesitve and Kidney Diseases, NIH.

\section{References}

Asselin-Labat ML, Sutherland KD, Barker H, Thomas R, Shackleton M, Forrest NC, Hartley L, Robb L, Grosveld FG, van der Wees J, et al. 2007. Gata-3 is an essential regulator of mammary-gland morphogenesis and luminal-cell differentiation. Nat Cell Biol 9: 201-209.

Buono KD, Robinson GW, Martin C, Shi S, Stanley P, Tanigaki K, Honjo T, Hennighausen L. 2006. The canonical Notch/RBP-J signaling pathway controls the balance of cell lineages in mammary epithelium during pregnancy. Dev Biol 293: 565-580.

Choi YS, Chakrabarti R, Escamilla-Hernandez R, Sinha S. 2009. Elf5 conditional knockout mice reveal its role as a master regulator in mammary alveolar development: Failure of Stat5 activation and functional differentiation in the absence of Elf5. Dev Biol 329: 227241.

Cui Y, Riedlinger G, Miyoshi K, Tang W, Li C, Deng CX, Robinson GW, Hennighausen L. 2004. Inactivation of Stat5 in mouse mammary epithelium during pregnancy reveals distinct functions in cell proliferation, survival, and differentiation. Mol Cell Biol 24: 8037-8047.

Gunther EJ, Belka GK, Wertheim GB, Wang J, Hartman JL, Boxer RB, Chodosh LA. 2002. A novel doxycycline-inducible system for the transgenic analysis of mammary gland biology. FASEB J 16: 283-292.

Harris J, Stanford PM, Sutherland K, Oakes SR, Naylor MJ, Robertson FG, Blazek KD, Kazlauskas M, Hilton HN, Wittlin S, et al. 2006. Socs2 and elf5 mediate prolactin-induced mammary gland development. Mol Endocrinol 20: 1177-1187.

Hennighausen L, Robinson GW. 2005. Information networks in the mammary gland. Nat Rev Mol Cell Biol 6: 715-725.

Hennighausen L, Robinson GW. 2008. Interpretation of cytokine signaling through the transcription factors STAT5A and STAT5B. Genes \& Dev 22: 711-721.

Hoelbl A, Kovacic B, Kerenyi MA, Simma O, Warsch W, Cui Y, Beug H, Hennighausen L, Moriggl R, Sexl V. 2006. Clarifying the role of Stat5 in lymphoid development and Abelson-induced transformation. Blood 107: 4898-4906.

Kouros-Mehr H, Slorach EM, Sternlicht MD, Werb Z. 2006. GATA-3 maintains the differentiation of the luminal cell fate in the mammary gland. Cell 127: 1041-1055.

Li G, Wang Z, Zhang Y, Kang Z, Haviernikova E, Cui Y, Hennighausen L, Moriggl R, Wang D, Tse W, et al. 2007. STAT5 requires the $\mathrm{N}$-domain 
to maintain hematopoietic stem cell repopulating function and appropriate lymphoid-myeloid lineage output. Exp Hematol 35: 1684-1694

Liu X, Robinson GW, Wagner KU, Garrett L, Wynshaw-Boris A, Hennighausen L. 1997. Stat5a is mandatory for adult mammary gland development and lactogenesis. Genes \& Dev 11: 179-186.

Liu X, Gallego MI, Smith GH, Robinson GW, Hennighausen L. 1998. Functional rescue of Stat5a-null mammary tissue through the activation of compensating signals including Stat5b. Cell Growth Differ 9: 795-803.

Liu F, Kunter G, Krem MM, Eades WC, Cain JA, Tomasson $\mathrm{MH}_{\text {, }}$ Hennighausen L, Link DC. 2008. Csf3r mutations in mice confer a strong clonal HSC advantage via activation of Stat5. J Clin Invest 118: 946-955.

Miyoshi K, Shillingford JM, Smith GH, Grimm SL, Wagner KU, Oka T, Rosen JM, Robinson GW, Hennighausen L. 2001. Signal transducer and activator of transcription (Stat) 5 controls the proliferation and differentiation of mammary alveolar epithelium. J Cell Biol 155: 531542.

Oakes SR, Naylor MJ, Asselin-Labat ML, Blazek KD, Gardiner-Garden M, Hilton HN, Kazlauskas M, Pritchard MA, Chodosh LA, Pfeffer PL, et al. 2008. The Ets transcription factor Elf5 specifies mammary alveolar cell fate. Genes \& Dev 22: 581-586.

Renou JP, Bierie B, Miyoshi K, Cui Y, Djiane J, Reichenstein M, Shani M, Hennighausen L. 2003. Identification of genes differentially expressed in mouse mammary epithelium transformed by an activated $\beta$-catenin. Oncogene 22: 4594-4610.

Shackleton M, Vaillant F, Simpson KJ, Stingl J, Smyth GK, Asselin-Labat ML, Wu L, Lindeman GJ, Visvader JE. 2006. Generation of a functional mammary gland from a single stem cell. Nature 439: 84-88.

Shillingford JM, Miyoshi K, Flagella M, Shull GE, Hennighausen L. 2002. Mouse mammary epithelial cells express the $\mathrm{Na}-\mathrm{K}-\mathrm{Cl}$ cotransporter, NKCC1: Characterization, localization, and involvement in ductal development and morphogenesis. Mol Endocrinol 16: 1309-1321.

Stingl J. 2009. Detection and analysis of mammary gland stem cells. J Pathol 217: 229-241.

Stingl J, Eirew P, Ricketson I, Shackleton M, Vaillant F, Choi D, Li HI, Eaves CJ. 2006. Purification and unique properties of mammary epithelial stem cells. Nature 439: 993-997.

Teglund S, McKay C, Schuetz E, van Deursen JM, Stravopodis D, Wang D, Brown M, Bodner S, Grosveld G, Ihle JN. 1998. Stat5a and Stat5b proteins have essential and nonessential, or redundant, roles in cytokine responses. Cell 93: 841-850.

Udy GB, Towers RP, Snell RG, Wilkins RJ, Park SH, Ram PA, Waxman DJ, Davey HW. 1997. Requirement of STAT5b for sexual dimorphism of body growth rates and liver gene expression. Proc Natl Acad Sci 94: 7239-7244.

Wagner KU, Wall RJ, St-Onge L, Gruss P, Wynshaw-Boris A, Garrett L, Li M, Furth PA, Hennighausen L. 1997. Cre-mediated gene deletion in the mammary gland. Nucleic Acids Res 25: 4323-4330.

Wagner KU, McAllister K, Ward T, Davis B, Wiseman R, Hennighausen L. 2001. Spatial and temporal expression of the Cre gene under the control of the MMTV-LTR in different lines of transgenic mice. Transgenic Res 10: $545-553$.

Wang Z, Li G, Tse W, Bunting KD. 2009. Conditional deletion of STAT5 in adult mouse hematopoietic stem cells causes loss of quiescence and permits efficient nonablative stem cell replacement. Blood 113: 4856-4865.

Yao Z, Cui Y, Watford WT, Bream JH, Yamaoka K, Hissong BD, Li D, Durum SK, Jiang Q, Bhandoola A, et al. 2006. Stat5a/b are essential for normal lymphoid development and differentiation. Proc Natl Acad Sci 103: 1000-1005. 


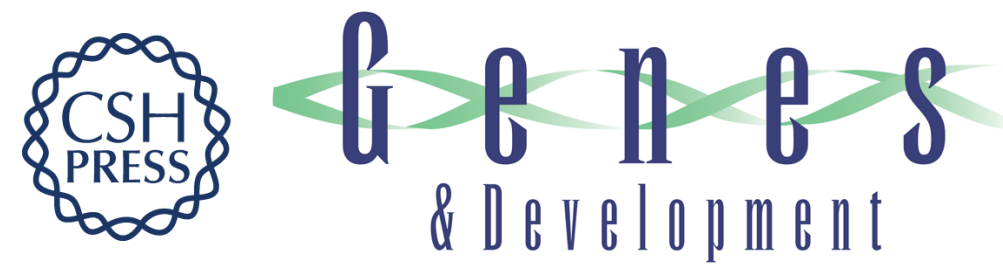

\section{Development of mammary luminal progenitor cells is controlled by the transcription factor STAT5A}

Daisuke Yamaji, Risu Na, Yonatan Feuermann, et al.

Genes Dev. 2009, 23:

Access the most recent version at doi:10.1101/gad.1840109

Supplemental http://genesdev.cshlp.org/content/suppl/2009/10/15/23.20.2382.DC1
Material

References This article cites 27 articles, 10 of which can be accessed free at:

http://genesdev.cshlp.org/content/23/20/2382.full.html\#ref-list-1

License

Email Alerting

Receive free email alerts when new articles cite this article - sign up in the box at the top

Service

right corner of the article or click here.

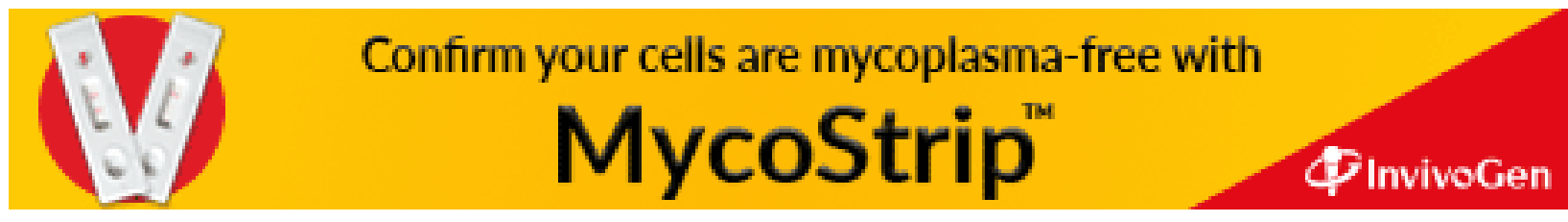

